\title{
ABANDONING NARRATIVES OF MUSIC AND PROSE
}

\author{
Arnold Schönberg and James Joyce
}

By Norbert Bachle itner (Vienna)

The works of these two key Modernist artists exhibit a number of similar features: Joyce's abandonment of personal and representational narration can be likened to Schönberg's rejection of functional theories of harmony. Through rational constructions - based on structural constraints such as twelve-tone sequences and the Gilbert and Linati schemata - both artists systematically explore the limits and possibilities of their chosen material, with Schönberg's emancipation of dissonance and Joyce's highly artificial idiom in ,Finnegans Waker expanding the possibilities of associating musical or literary meaning.

Das Werk dieser beiden ,Leuchttürme' der Moderne weist zahlreiche Ähnlichkeiten auf: Sie verabschieden das persönliche und mimetische Erzählen bzw. die klassische Funktionsharmonik; mit Hilfe rationaler Konstruktion aufgrund struktureller Vorgaben wie der Zwölftonreihen und der Gilbert und Linati Schemata messen sie systematisch Möglichkeitsräume aus; Schönbergs Konzept der Emanzipation der Dissonanz und die höchst artifizielle Sprache von 'Finnegans Waker entgrenzen den Spielraum für die musikalische bzw. literarische Bedeutungszuweisung.

\section{Introduction}

A comparison between Schönberg and Joyce is a challenging project that, in its first stages, can only yield provisional results. Undoubtedly both artists, in their respective disciplines, are key Modernist figures. $\left.{ }^{1}\right)$ To what extent, however, do their works and modes of production exhibit common features - beyond the universal characteristics of the avant-garde - that make for a meaningful com-

1) This rating hardly needs any justification, we would like to provide some evidence, though: I) The >Bibliographie des Musikschrifttums onliner<http://www.musikbibliographie.de> [25.06.2019] contains 2935 entries dedicated to Schönberg - the numbers for other important composers are R. Strauss I887, B. Bartók I480, I. Strawinsky 942, A. Berg 830, and A. von Webern 716. - 2) According to the publication database of the 'Modern Language Association Joyce attracted more attention from researchers than any other author: the database documents 2302 entries, V. Woolf counts 1705 entries, Kafka I 197, Borges 1075 and Proust 997 (numbers taken from a lecture by David Damrosch at the University of Vienna on 23 July 2016). 
parison? There seem to be no direct connections between the two artists, such as meetings or references to one another in letters or notes. Our intermedial comparison, therefore, tries to establish parallels between works that emerged independently from each other. Due to the constraints of this paper, we concentrate on Schönberg's twelve-tone composition technique and Joyce's mode of writing in ,Ulysses and (Finnegans Wake ${ }^{2}$ ) Earlier works by both artists will be excluded from this article.

Both Joyce and Schönberg took innovative steps around a similar time period. In 1908 Joyce began the preparations for 'Ulysses, with the actual writing process beginning in 19I4, and completed by I92I. The experimental elements of Joyce's writing either appear in the later chapters of the novel or were inserted in the earlier chapters during the last revision of the text (in 192I/22). ${ }^{3}$ ) In 1923 Joyce began preparations for his ,Work in Progress that finally appeared in 1939 under the title 'Finnegans Waker. Schönberg maintains that his compositions started to move away from a tonal center around 1908. ${ }^{4}$ ) The twelve tones of the chromatic scale in a continuous sequence, however, are already apparent at the beginning of the fourth movement of his second String quartet (op. I0, 1907/08). In the following decade Schönberg's piano pieces show a continuous movement

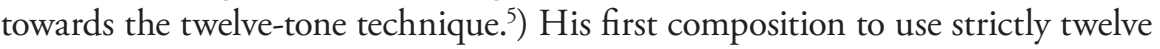
tones ("erste strenge Komposition mit zwölf Tönen"), ${ }^{6}$ ) the Suite for piano (op. 25), dates from I92I. In July of the same year he famously informed his pupil Josef Rufer that he had that day found something that would guarantee the supremacy of German music for the next hundred years ("heute habe er etwas gefunden, das der deutschen Musik die Vorherrschaft für die nächsten hundert Jahre sichere”).”)

${ }^{2}$ ) Christopher Butler, Joyce, Modernism and Post-modernism, in: The Cambridge Companion to James Joyce, ed. by Derex Attridge, Cambridge i99o, pp. 259-282, compares Schönberg's and Joyce's pre-modernist works that testify to the "complete recreative and parodic mastery of previous traditions" (p. 263), whereas their "formally extremely complicated works [...] are independent of the usual mimetic aims associated with a particular content" (pp. 275-276). Butler refers to 'Stephen Hero (1904-1906) and `Pelléas et Mélisander (1902/03), ,Finnegans Waker (1939) and 'Moses und Aaron (1930-1932), respectively. Both parameters of comparison seem to be too general to yield significant results.

$\left.{ }^{3}\right)$ For instance the intermediate titles resembling newspaper articles in chapter seven; see Hugh Kenner, Ulysses, London 1980, p. 7i, and Arnold Goldman, The Joyce Paradox. Form and Freedom in His Fiction, London 1966, p. 83.

$\left.{ }^{4}\right)$ Arnold Schönberg, Composition with Twelve Tones, in: A. S., Style and Idea, New York I959, pp. I02-I43, here: p. IO5.

5) Claus Ganter, Ordnungsprinzip oder Konstruktion? Die Entwicklung der Tonsprache Arnold Schönbergs am Beispiel seiner Klavierwerke, München, Salzburg 1997, analyses the piano pieces op. II, I9, 23, and 25 in this respect.

$\left.{ }^{6}\right)$ Arnold Schönberg, Komposition mit zwölf Tönen, in: A. S., Stil und Gedanke. Aufsätze zur Musik, ed. by Ivan Vojtěch, Frankfurt/M I976, pp. 380-383, here: p. 382.

7) Josef Rufer, Das Werk Arnold Schönbergs, Kassel, London, New York I959, p. 26. The quotation is probably not exact, especially the nationalist wording is more than doubtful; 
As we have already stated above, due to the lack of any evidence of direct contact between Schönberg and Joyce any exploration of possible influence is futile. Moreover, the question of the 'musicalization' of Joyce's prose - most obvious for instance in Chapter Eleven of ,Ulysses - and Schönberg's treatment of literary texts will not be covered in this article. The following comparison instead draws parallels between the technique of composition and the style of writing of these two key representatives of musical and literary Modernism. Both of them use their 'material', namely the language and the tonal system, experimentally. Literature and music represent "conventionalised human signifying practices [...], each of which is governed by a (historically variable) 'grammar' (generic conventions, the tonal system etc.)". ${ }^{8}$ ) A major difference, however, emerges when considering the importance of sound. With the exception of poetry, sound is, in general, of low importance in literature, and especially in prose. Compared to music, literature is a semantic medium or art; in music sounds are simply sounds, whereas the sounds employed in literature - by the arbitrary association of external meanings - are not only sounds but words ("[...] die Laute, aus welchen das Material der Musik besteht, [sind] einfach Laute, während diejenigen, aus welchen das Material der Literatur besteht, durch die Zuweisung willkürlicher äußerer Bedeutungen nicht lediglich Laute, sondern Wörter sind.") $)^{9}$

Schönberg and Joyce both break the traditional rules of artistic creation, through the rejection of habitual melodic and harmonic practices and accustomed linguistic usage, in particular motifs, modes of narration, and the clichés developed by literary realism. By composing with twelve tones, Schönberg intended to reform musical 'grammar' in his works by presenting a radical contrast to former musical conventions. In particular he abandoned the classical theory of harmony, of significance in the $18^{\text {th }}$ and $19^{\text {th }}$ centuries, by reverting to Bach's polyphonic and contrapunctual modes of composition..$^{10}$ ) Moreover, he wanted to change or even destroy the "culturally assigned connotations" of

see E. Randol Schoenberg, The Most Famous Thing He Never Said, in: Journal of the Arnold Schönberg Center 5 (2003), pp. 27-30. - For a detailed chronology of the development of the composition with twelve tones from I92 I to I924 see Therese Muxeneder, Arnold Schönbergs Verkündung der Zwölftonmethode - Daten, Dokumente, Berichte, Anekdoten, in: Journal of the Arnold Schönberg Center 7 (2005), pp. 30I-3I3.

$\left.{ }^{8}\right)$ Werner Wolf, The Musicalization of Fiction. A Study in the Theory and History of Intermediality, Amsterdam, Atlanta, GA I999, p. I2.

9) Calvin S. Brown, Theoretische Grundlagen zum Studium der Wechselverhältnisse zwischen Literatur und Musik, in: Literatur und Musik. Ein Handbuch zur Theorie und Praxis eines komparatistischen Grenzgebietes, ed. by Steven Paul Scher, Berlin 1984, pp. 28-39, here: p. 30 .

${ }^{10}$ ) Bach is one of the major musical authorities for Schönberg and the 'second' Viennese school of music. 
music. $\left.{ }^{11}\right)$ Compared to literature, music is characterized by the dominance of internal relations: in general, tones refer to the other tones that surround them and not to an extra-musical reality. ${ }^{12}$ )

Schönberg intended to change listening habits by emancipating the dissonance. Like many theoreticians, he started with a discussion of overtones as the foundation of the 'natural' or 'absolute' musical system. The classical theory of harmony privileges the first few overtones as the first, third, and fifth elements of the overtone row form a major triad. The tones of the dominant and subdominant major triads and of the triads in the parallel minor keys are also located in the lower part of the overtone row. As a consequence, major thirds, fifths, and major sixths are considered to sound pleasant, harmonious, agreeable, cheerful, or even comforting. Fourths and sevenths are located in a neutral harmonic mid-field, whereas seconds, the minor third, and the flatted fifth are relegated as disagreeable sounds admitted only as transit tones. As Schönberg argued and demonstrated, this classification is neither 'natural' nor unchangeable, but is rather based solely on specific cultural traditions and listening habits. ${ }^{13}$ ) Its acceptance is due to musical socialization rather than to 'nature'. Music ethnology demonstrates that tonal systems vary greatly according to culture and tradition. Listening to and enjoying music is primarily based on comprehension. "What distinguishes dissonances from consonances is not a greater or lesser degree of beauty, but a greater or lesser degree of comprehensibility." ${ }^{14}$ ) In a similar way, grammatical and stylistic rules are not inherent to language and the same applies to literary norms, such as the conventions of realistic narration.

Tonality and functional harmony - dominant in Western music from Vivaldi to Beethoven - have both been compared to narrative literary forms, and in particular to the Bildungsroman. Susan McClary explains:

The background of a tonal composition [...] proceeds through a series of arrivals, beginning in the tonic key, moving through a few other keys, and returning finally home to the tonic. This background thereby traces a trajectory something like a quest narrative, with return to and affirmation of original identity guaranteed in advance..$^{15}$ )

$\left.{ }^{11}\right)$ Cf. Wolf, The Musicalization of Fiction (cit. fn. 8), p. 23.

$\left.{ }^{12}\right)$ Schönberg called the method of composition with twelve tones relating exclusively to one another the twelve-tone technique; qtd. in Ganter, Ordnungsprinzip oder Konstruktion (cit. fn. 5), p. 32.

13) An example of 'musical rhetorics' that codify the arousal of anger, compassion, anxiety or joy by musical means is the system of 'figures' used from the $16^{\text {th }}$ to the $18^{\text {th }}$ century in central and northern Germany by protestant precentors; see Gunnar Hindrichs, Art. "Sprache und Musik", in: Handbuch Literatur \& Musik, ed. by Nicola Gess und Alexander HoNOLD unter Mitarbeit von Sina Dell' Anno, Berlin, Boston 20I7, pp. 19-38, here: pp. $26 \mathrm{f}$.

14) Schönberg, Composition with Twelve Tones (cit. fn. 4), p. I04.

15) Susan McClary, Conventional Wisdom. The Content of Musical Form, Berkeley, London 2000 , p. 65 . 
The succession of hierarchically related harmonies produces coherence, creates suspense, and gives a sense of expectation as to musical progression. The concept of classical music represents Enlightenment ideals such as reason (rational effort resulting finally in the attainment of goals), purposeful advancement (waiting patiently and confidently for the pay-off), and the compatibility of social order and inner feelings. ${ }^{16}$ ) Other important features of the classical musical narrative are the "confidence in mimesis", especially of human interiority, of passions and feelings, and of a "centered subjectivity" ${ }^{17}$ ) that may be expressed and traced by the audience throughout a piece of music. In analogy with the Bildungsroman, a concerto, sonata, or symphony movement demonstrates and performs "the narrative formation of an autonomous musical self as it ventures into other terrains, strengthens its innate resources through motivic development, and finally consolidates the secure identity that confirms the viability of the centered subject." ${ }^{18}$ ) These musical conventions guarantee the listener a high degree of consolation and reconciliation. During the $19^{\text {th }}$ century, concepts and ideals such as the attainment of happiness through reasonable behaviour, the harmony of the individual and society, or a belief in the possibility of communicating one's feelings and the integrity of the subject become suspect and doubtful. Atonal music, and in particular music composed with the twelve-tone technique, is fragmented into a succession of tiny units and, therefore, no longer relies on long spans of tension. If tonality creates narrative music, atonality may be considered to engender self-referential and "consciously ANTI-narrative" music. ${ }^{19}$ )

\section{2. "Emancipation of Dissonance:" Schönberg's Twelve-Tone Technique}

Adorno's remarks about dodecaphony in his 'Philosophie der neuen Musik serve as a guide when comparing Schönberg and Joyce. ${ }^{21}$ ) In a footnote of this

${ }^{16)}$ Cf. ibid., pp. $67 f$.

${ }^{17}$ ) Cf. ibid., p. 70 and 73.

${ }^{18)}$ Ibid., p. IO2.

19) Susan McClary, The Impromptu That Trod on a Loaf: or How Music Tells Stories, in: Narrative, 5-I (1997), pp. 20-35, here: p. 2I. McClary includes Philip Glass's minimalism, blues, and rap in this tendency towards fragmentation.

$\left.{ }^{20}\right)$ Schönberg, Composition with Twelve Tones (cit. fn. 4), p. I04.

$\left.{ }^{21}\right)$ The fact that Adorno's judgements about the twelve-tone technique are sometimes doubtful and that he got into disputes with Schönberg about these questions does not matter here. For the relation between Schönberg and Adorno and their respective comments on each other cf. Ludwig Holtmeier, Cosima Linke, Schönberg und die Folgen, in: Adorno-Handbuch. Leben - Werk - Wirkung, ed. by Richard Klein, Johann Kreuzer and Stefan MüllerDooнm, Stuttgart, Weimar 20I I, pp. II9-I39. 
treatise, Adorno even mentions Joyce alongside Picasso, Kafka, and Proust as artists who - like Schönberg - produced fragmentary works critical of tradition. ${ }^{22}$ ) While this enumeration could be interpreted as mere name-dropping, a look at Adorno's essay `Der Standort des Erzählers im zeitgenössischen Roman explains why Joyce is included. In this essay Adorno discusses the general alienation of the individual that leads to the abandonment of personal narrators and renders the idea of mimesis obsolete. The rebellion of the novel against realism ("Rebellion des Romans gegen den Realismus") instigated by Joyce is connected with a rebellion against discursive language and the emancipation from the representational ("Emanzipation vom Gegenstand"). ${ }^{23}$ ) On the other hand, Proust stands for the subjective disintegration of narration, namely the micrological technique that finally fractures the unity of life into atoms ("mikrologische Technik, unter der schließlich die Einheit des Lebendigen nach Atomen sich spaltet"). ${ }^{24}$ )

Returning to Adorno's remarks about dodecaphony in Philosophie der neuen Musikı, a particularly striking passage compares musical composition and writing within the context of the consequences of dodecaphony:

Paralysis of the spontaneity of composition is also paralysis of the spontaneity of the advanced composers. They are confronting the same unsolvable tasks as writers who have to establish the vocabulary and the syntax for every single sentence they write.

(Gelähmt wird mit der Spontaneität der Komposition auch die Spontaneität der avancierten Komponisten. Sie sehen sich vor so unlösbare Aufgaben gestellt wie ein Schriftsteller, der für jeden Satz, den er schreibt, Vokabular und Syntax eigens beistellen muß..25)

Adorno agrees that it is necessary to renounce traditional melodics and theories of harmony; he regards this as a sort of purgation of musical material ("eine Art Reinigung des musikalischen Materials") that becomes cleansed of the dross of the mere organic ("von den Schlacken des bloß Organischen gereinigt"). ${ }^{26}$ ) On the other hand, this process of purification leads to loss: the composer's creativity and spontaneity are drastically restricted. Adorno criticises the atomization of small musical phrases ("Atomisierung der musikalischen Partialmomente"), the corresponding neglect of the over-all form of the work, and the loss of musical meaning ("musikalischen Sinns"). ${ }^{27}$ ) Focusing on the material and its principles results in a transition from organic music to the hegemony of the

22) Theodor W. Adorno, Philosophie der neuen Musik, Frankfurt/M I978, p. I20.

23) Theodor W. Adorno, Standort des Erzählers im zeitgenössischen Roman, in: T. W. A., Noten zur Literatur, Frankfurt/M i98I, pp. 4I-48, here: pp. 4If.

$\left.{ }^{24}\right)$ Ibid., p. 44 .

${ }^{25}$ ) Adorno, Philosophie der neuen Musik (cit. fn. 22), p. Ior; engl. translation N. B.

26) Theodor W. Adorno und Ernst KreneK, Briefwechsel, Frankfurt/M i974, letter of April 9th, I929, p. I4.

${ }^{27}$ ) Adorno, Philosophie der neuen Musik (cit. fn. 22), p. I07. 
number, to the cult of sheer proportion ("Kultus der reinen Proportionen") ${ }^{28}$ ), and to an abstention from expressing oneself by means of music.

Seriality and aleatoric techniques are clearly anti-subjectivist modes of composition. ${ }^{29}$ ) Contrary to conventional works of art, modern art is characterised by disruption; a medium dedicated to the expression of feelings has turned into a medium of thought, criticism, and self-reflection. Rational composition has ruled out the expressive function of music, dodecaphony in particular is dependent on the musical 'material' and not on the composer's expressive intentions. Instead of expressing emotions, music registers corporeal agitations of the unconscious, shocks, and traumas ("leibhafte Regungen des Unbewußten, Schocks, Traumata"). ${ }^{30}$ ) Adorno's association of music and the unconscious reminds us that Joyce's mode of writing in 'Finnegans Wake has been repeatedly characterized as relying on linguistic auto-generation and of thus rendering a dream reality. According to Adorno, the formal constraints and strict rules of a twelve-tone composition mirror the repression and alienation or even destruction of the individual in modern society. He therefore, proposes emancipation from this technique and the return to spontaneity, intuitive creativity and freedom of action ("Freiheit der Aktion"). ${ }^{31}$ )

In his >Harmonielehre` (I9II) Schönberg, if we follow Adorno, had defined the representation of inner nature ("Wiedergabe der inneren Natur") as the highest task of art. Its only purpose is the imitation of impressions that - associated with each other and with other sensory impressions - form new structures and new movements ("Nur die Nachahmung der Eindrücke, die nun durch Assoziation untereinander und mit anderen Sinneseindrücken Verbindungen zu neuen Komplexen, zu neuen Bewegungen eingegangen sind, ist ihr Zweck.”) $)^{32}$ ) In contrast with this rather traditional definition, the twelve-tone composition tries to relegate music 'with a purpose' to the background. The twelve tones should be equal and equivalent in order to avoid the feeling of a tonic, which is simply tonality. As soon as tonality is overcome, the tones lose their fixed harmonic function or 'meaning'. The feeling of a tonic may be abandonded by avoiding the repetition of identical tones before all the other tones have been used. In other words, the twelve tones should be used with the same numerical frequency.

${ }^{28)}$ Ibid.

${ }^{29}$ ) Cf. Melanie Wald-Fuhrmann, Musik und Subjektivität, in: Historische Musikwissenschaft, ed. by Michele Calella und Nikolaus Urbanek, Stuttgart, Weimar 2013, pp. 289-306, here: p. 303.

30) Adorno, Philosophie der neuen Musik (cit. fn. 22), p. 44

${ }^{31}$ ) Ibid., p. II I.

32) Arnold Schönberg, Harmonielehre, 4. Auflage, Wien, Zürich, London 1922 (first ed. I9II), p. I4. 
In the following, we offer a few examples taken from the piano piece op. 25 , Schönberg's first composition to use strictly twelve tones. ${ }^{33}$ ) The basis for each composition with twelve tones is a sequence (or 'row') of tones called the prime series (or 'Grundgestalt'). In the case of op. 25, this row is composed of minor and major seconds, minor thirds, and (augmented) fourths (fig.1):

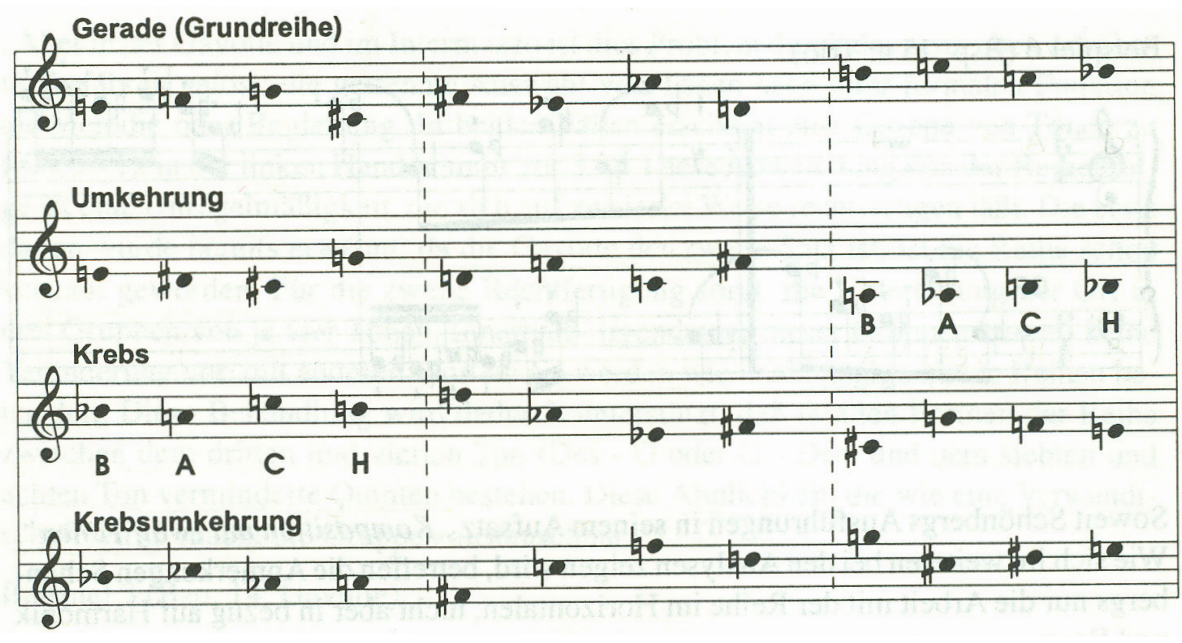

The inversion includes the famous sequence B-A-C-H, a clear reverence to Baroque musical tradition. The prelude to the piece introduces the prime series in the upper voice combined with a canonically retarded duplication of the same row in the bass voice, starting seven half-tones above the basic prime series (abbreviated G VII). In the second half of the second measure, the tones 9 to I2, starting from the f, i. e., still taken from G VII, are shifted underneath the tones 5 to 8 . The tones of the series are numbered here for purpose of analysis only. Moreover, the appearance of the retrograde sequence of B-A-C-H and the changes of metre from $6 / 8$ to $3 / 4$ and $12 / 16$ are also marked (fig. 2):

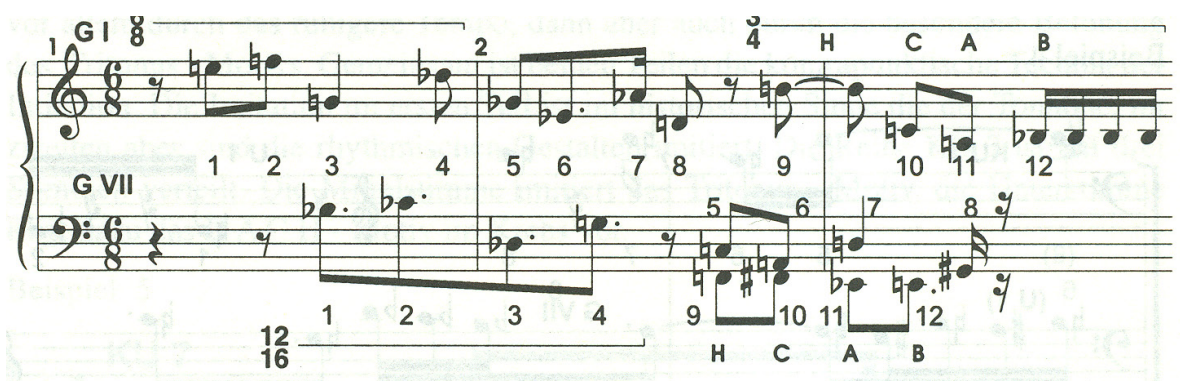


After the introduction of the prime series, a number of variations of the basic sequence begin. The three basic modes of transposition of the prime series, amply used by Schönberg but obviously derived from Baroque rules of counterpoint composition, are the inversion ('Umkehrung'), the retrograde ('Krebs'), and the retrograde inversion ('Krebs-Umkehrung'). In measures 5 and 6 Schönberg employs the retrograde starting on the seventh half-tone (K VII) and on the keytone (K I) (fg. 3):

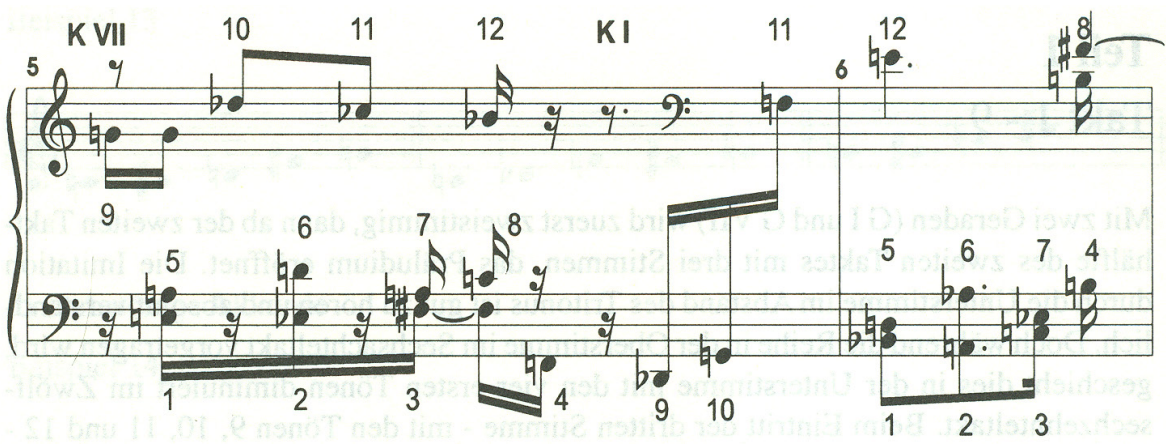

Crucially, the horizontal succession of tones may be transferred to the vertical axis, i. e. melodies are converted into chords. The number of voices may thus be augmented to three or four as in measures 22 to 25 . The rows used here are inversion I, retrograde inversion VII, prime series VII, and retrograde I (s. Fig. 4).

Often groups of three, four, or even six successive tones are taken from the series, but the tones may be rather freely distributed on the horizontal and vertical axes as in the following example taken from the gigue, measures 43 and 44 (s. Fig. 5).

The relationship between freedom of choice and determination by sequence (and strict rules of musical development from this sequence) is hard to determine. It seems that there is most freedom at the beginning, with the choice of the sequence becoming more constrained over the course of composition. Whenever a number of notes (e. g. I, 2, 5, 6, 9, 10) have been used, the remaining notes $(3,4,7,8$, I I, I2) must then definitely be employed. Schönberg was fascinated with the potential of magic squares and his scores, which are readable in all directions, are sometimes reminiscent of such squares. Another possible association that arises with this method of writing music are Sudoku puzzles.

33) All examples are taken from Ganter, Ordnungsprinzip oder Konstruktion (cit. fn. 5), pp. 226, 23I, 232, 239, and 299. 


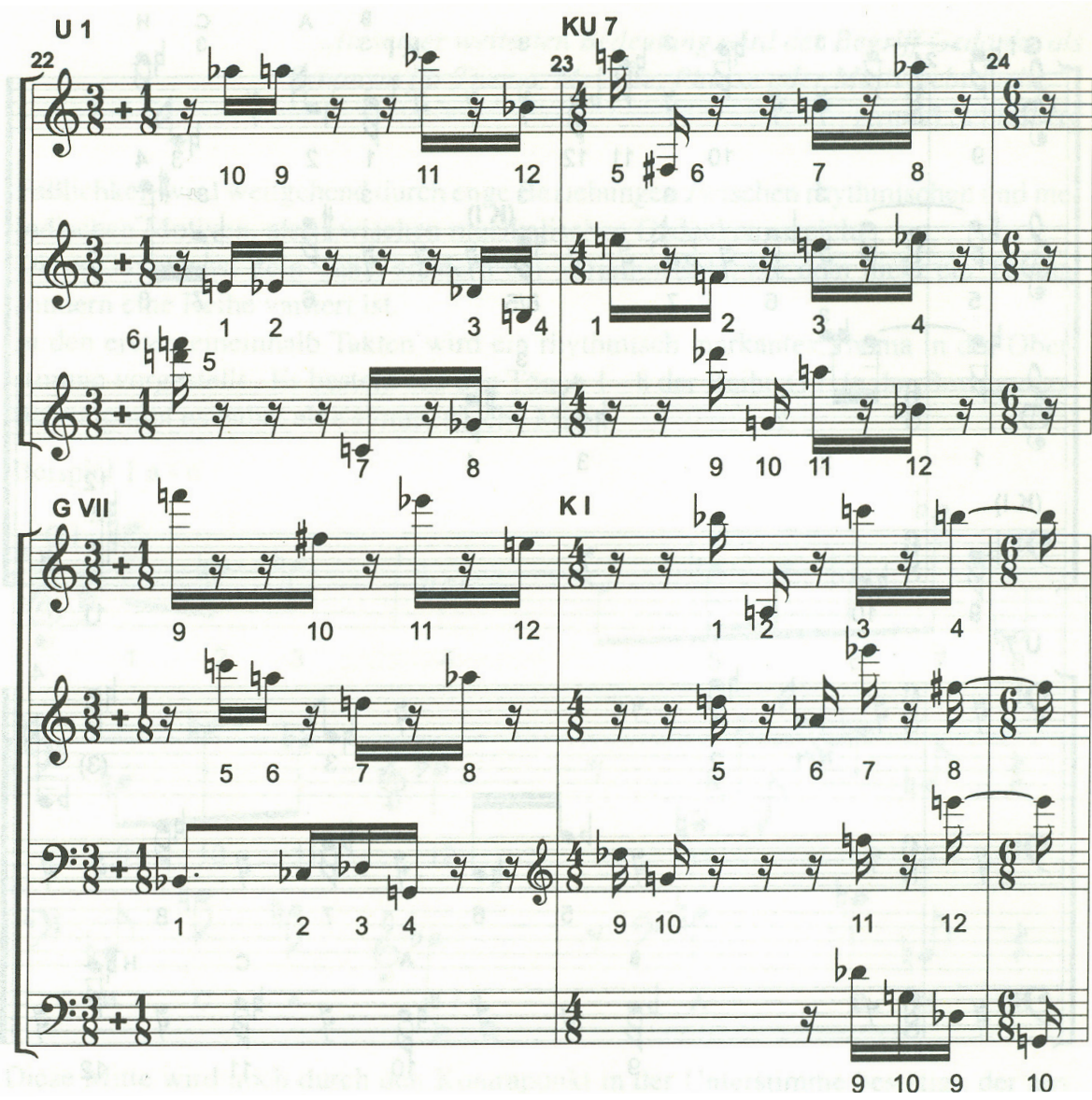

The general ratio behind the complicated procedures of avoiding conventional chords and cadences is the urge to divest the single tone of its privilege of supremacy ("der einzelne Ton des Privilegs der Vorherrschaft beraubt"), which is another way of describing the emancipation of dissonance. ${ }^{34}$ ) As early as in the 'Harmonielehre`, Schönberg had already maintained that tonality is no eternal natural law of music ("kein ewiges Naturgesetz der Musik") ${ }^{35}$ ) and that the difference between consonance and dissonance is not absolute but fluid - it actually depends on the distance of the overtones from the keynote.

${ }^{34}$ ) Schönberg, Komposition mit zwölf Tönen (cit. fn. 6), p. 38I.

${ }^{35}$ ) Schönberg, Harmonielehre (cit. fn. 32), p. 4. 
Beispiel 15

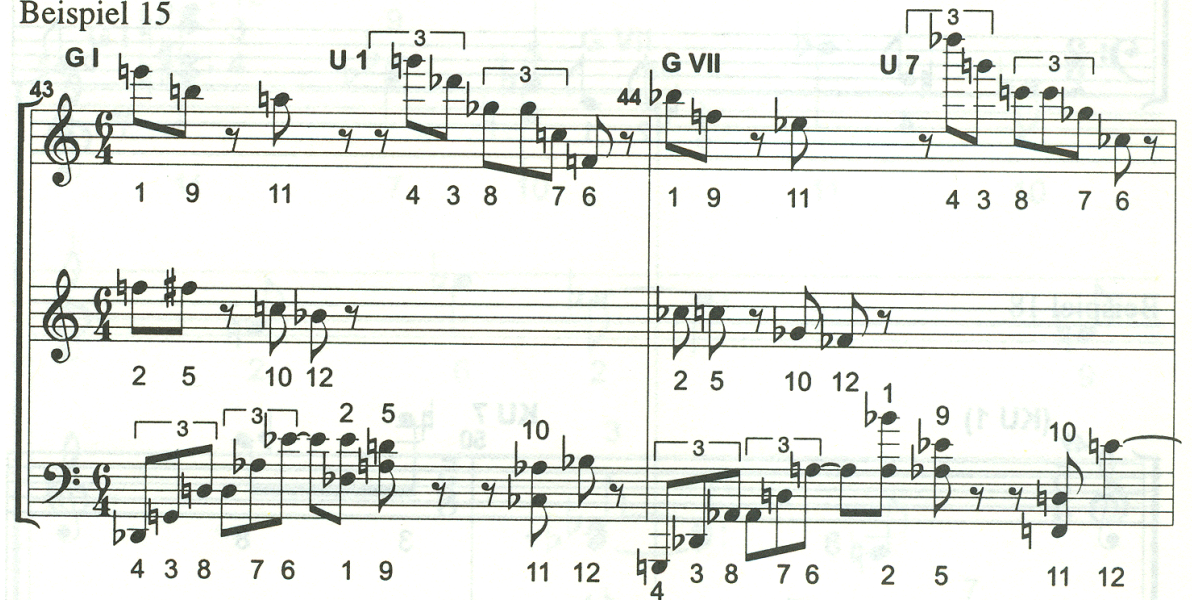

It is necessary to increase the capability of the analytical ear in order to be able to become acquainted with the overtones that are far away from the keynote and thereby extend the concept of artistically acceptable euphony to include the whole range of natural phenomena.

(Es hängt nur von der wachsenden Fähigkeit des analytischen Ohrs ab, sich auch mit den fernliegenden Obertönen vertraut zu machen und damit den Begriff des kunstfähigen Wohlklanges so zu erweitern, daß die gesamte naturgegebene Erscheinung darin Platz hat.. ${ }^{36}$ )

It seems clear that these 'natural phenomena' comprise the physical and physiological foundations of music and the mathematical relations between the tones that define the sequence of overtones. They, however, do not lay down the rules of classical tonality and harmony. According to Schönberg, the human ear is as capable of perceiving the distant overtones that have a complex numerical relation with the keynote as precisely as the nearest overtones (octave, fifth, third etc.). In Harmonielehre he outlines the idea that the equality of the twelve tones should form the foundation of the theory of harmony. In his lecture on 'New Music, Outmoded Music, Style and Idear (1946) Schönberg retrospectively cloaks his suggestions for innovation in a sequence of negative phrases:

There should be avoided: chromaticism, expressive melodies, Wagnerian harmonies, romanticism, private biographical hints, subjectivity, functional harmonic progressions, illustrations, leitmotivs, concurrence with the mood or action of the scene and characteristic declamation of the text in opera, songs and choruses. In other words, all that was good in the preceding period should not occur now. ${ }^{37}$ )

$\left.{ }^{36}\right)$ Ibid., p. I8, engl. translation N. B.

${ }^{37}$ ) Arnold Schönberg, New Music, Outmoded Music, Style and Idea, in: A. S., Style and Idea. Selected Writings of Arnold Schoenberg, ed. by LeOnARD STEIn with translations by Leo Black, Berkeley and Los Angeles I984, Pp. II3-I24, here: p. I2O. 
In a manuscript entitled 'Constructed Music (c. 193I) the sober and constructive mode of composing is confronted with spontaneous music: "Music is assembled from notes". Similarly, the composer's creative influence, and especially their predilection for certain (consonant) intervals and chords, is limited. The highest possible praise for a composition is the statement "that it really is well worked-out". ${ }^{38}$ ) What matters in musical composition is ratio, not feeling: the thought as such, not its clothing, orchestration, decoration, tone-colour, or expressive performance. In this context Schönberg quotes a Beethoven anecdote:

I have often wondered whether people who possess a brain would prefer to hide this fact. I have been supported in my own attitude by the example of Beethoven who, having received a letter from his brother Johann signed "land owner", signed his reply "brain owner". ${ }^{39}$ )

We will not, however, further pursue Adorno's comments on dodecaphony or Schönberg's theory and practice of the new mode of composition; their recapitulation serves only to provide concepts and keywords that may be useful in our comparison with Joyce's innovations in literary writing.

\section{Joyce's Abandonment of Narrative Concreteness and Personal Narration, as Compared to Schönberg}

The abandonment of narrative concreteness and personal narration through the fragmentation of a text will serve as a point of departure in this section. Here we compare Schönberg's approach to composition with techniques of writing used in ,Ulysses, with traditional realist narration regarded as an equivalent to the theory of functional harmony applied in music of the Classical and Romantic eras. ${ }^{40}$ )

The first nine chapters of ,Ulysses are narrated (almost) entirely from a personal point of view, namely from Stephen Dedalus's and Leopold Bloom's perspective. Deviations from this type of narration appear for the first time in Chapter Ten ("Wandering Rocks") which is composed of eighteen short segments. $\left.{ }^{41}\right)$ The reader accompanies various figures as they simultaneously make

${ }^{38)}$ Arnold Schönberg, Constructed Music, in: A. S., Style and Idea (cit. fn. 37), pp. Io6-Io8, here: pp. 106 and 107.

$\left.{ }^{39}\right)$ Schönberg, New Music, Outmoded Music, in: A. S., Style and Idea (cit. fn. 37), p. I22.

$\left.{ }^{40}\right)$ In this respect we share the approach of Robin Gail Schulze, Design in Motion: Words, Music, and the Search for Coherence in the Works of Virginia Woolf and Arnold Schoenberg, in: Studies in the Literary Imagination 25, No. I (I992), pp. 5-22; unfortunately, Schulze does not go beyond very general observations of parallels between Woolf's decomposition of linear and causative narration and Schönberg's transgression of functional harmony.

${ }^{41}$ ) See Kenner, Ulysses (cit. fn. 3), p. 6r. 
their way through Dublin. The episode's technique seems mechanical: the segments fit into one another like cogs. ${ }^{42}$ ) This formation is, however, not made explicit by a narrator: representation speaks for itself. ${ }^{43}$ ) A similarly complex narrative formation can be observed in Chapter Eleven ("Sirens"), in which the narrative does not focus on any single character. In this chapter the materiality of language is finally foregrounded. This mode of narration tries to shift the mimesis of reality from the meaning of words to the sound of language ("die Mimesis der Wirklichkeit von dem Bedeutungsfeld der Wörter in das Lautund Schriftbild der Sprache zu verlegen"): ${ }^{44}$ ) Joyce imitates noises and musical sounds with words.

Franz Karl Stanzel sums up the loss of narrative unity in the novel:

The unity of personal narration presupposes a stable and constantly present centre that provides orientation [...]. In ,Ulysses this centre, this resting-point, does not exist anymore. All the narrative conventions depending on it such as unity of relation to a third-person or first-person narrator, a fixed point of observation and perspective etc. have become obsolete.

(Einheit der Erzählsituation setzt eine ruhende, Orientierung ausstrahlende, konstant dargestellte Mitte voraus [...]. Im ,Ulysses، existiert diese Mitte, dieser Ruhepunkt nicht mehr. Alle sich daraus ableitenden Erzählkonventionen, Einheit des Er-Bezuges oder des Ich-Bezuges, Fixierung des Beobachtungspunktes und der Perspektive usw., sind damit hinfällig geworden. $)^{45}$ )

In an even more radical fashion, Joyce continues the deconstruction of narration in Chapter Fifteen ("Circe"), where a number of dramatic voices compete with one another. If there is any narrative subject, it is reduced to the consciousness of the author during the conception of the text ("Bewußtsein des Autors im Augenblick des Konzeptionsprozesses"). ${ }^{46}$ ) While we could offer further examples of the dissolution of a narrative subject in the second half of ,Ulysses,, it seems sufficiently clear that this process resembles Schönberg's minimization of 'narrative' in his compositions by letting the musical material speak for itself.

From Chapter Ten onwards, the text of Ulysses also shows a focus on the materiality of language and the prioritization of language and style at the expense of a narrative interest in plot and characterization ("Dominanz von Sprache und Stil gegenüber dem narrativen Interesse an Handlungsfortgang und innen- wie außengeschauter Personendarstellung"). Hans Walter Gabler

${ }^{42)}$ Cf. Stuart Gilbert, Das Rätsel Ulysses, Frankfurt/M 1977, p. I82.

$\left.{ }^{43}\right)$ See Franz K. Stanzel, Die Erzählsituation im ,Ulysses`, in: James Joyces ,Ulysses‘. Neuere deutsche Aufsätze, ec. by Therese Fischer-Seidel, Frankfurt/M i977, pp. 255-283, here: p. 259.

${ }^{44}$ ) Ibid., pp. 26of. We do not go into the use of musical forms such as fugue, ouverture, song, rondo and many others, which has often been analysed already.

${ }^{45}$ ) Ibid., p. 273, engl. translation N. B.

$\left.{ }^{46}\right)$ Ibid., p. 274. 
observes the breakthrough of textual selfgeneration from language, motifs, and the personal substance of the text („Durchbruch zur Selbsterzeugung des Textes aus der sprachlichen, motivlichen und personellen Eigensubstanz des Werkes"). ${ }^{47}$ ) Joyce compared writing ,Ulysses` with tessellating ${ }^{48}$ ) - a statement similar to Schönberg's insistence that music be constructed rather than invented. In another quotation, Joyce indicates that words are set and combined rather than invented, that the writer uses pre-fabricated material: "I have the words already. What I am seeking is the perfect order of words in the sentence." ${ }^{\prime 49}$ ) Hugh Kenner, therefore, rightly calls the author of ,Ulysses an "arranger" ${ }^{50}$ ) The numerous intratextual references may, therefore, be interpreted as a way of working with material that is already there, waiting to be used. From Chapter Fifteen onwards the text becomes literally self-generating:

We might say, then, that by its fifteenth chapter, ,Ulysses ' has begun to provide its author enough in the way of material to become self-perpetuating. The cross-referencing which the author had injected before to remind us of similarities between characters [...] here takes on an appearance of autonomy, as 'characters' belonging to other contexts or even ontological levels rise up to confront the characters in the Dublin action [...]. $\left.{ }^{51}\right)$

The analogy with dodecaphony is established through both the preparation of the 'material', i. e. the sequence of tones, and of afterwards working with it. If this procedure is not strictly equivalent to self-generation, it is, however, clear that artistic production is strictly regulated and leads to unintentional and 'unusual' sequences and combinations of tones. In the quotation above we could insert 'tones' (instead of 'characters') that appear in an unconventional musical context and are, therefore, deprived of their accustomed tonal function. As we have already mentioned, Adorno criticises the emancipatory intentions of dodecaphony which end up in repression and constraint, causing the individual to disappear behind the material - and allegedly natural - laws of composition.

Music is not idiom any longer, does not stand for traditions fixed in traditional forms any more. Together with this objective element expression fades, too. Formerly, the urge to intensify expression had neglected the traditional dimension of musical language. [...] Finally, from the dialectics the natural material emerges in a threateningly pure form.

(Musik hört auf, Idiom zu sein, in überlieferten Formen für fest Überliefertes einzustehen. Dort aber zergeht in eins mit eben diesem objektiven Element der Ausdruck, dessen Stei-

${ }^{47}$ ) Hans Walter Gabler, Werkentstehung und Textsituation des ,Ulysses`, in: James Joyces ,Ulyssesı. Neuere deutsche Aufsätze (cit. fn. 43), pp. 58-79, here: pp. 66 and 67.

$\left.{ }^{48}\right)$ Qtd. in Phillip F. Herring, Zur Textgenese des ,Ulysses: Joyces Notizen und seine Arbeitsmethode, in: James Joyces ,Ulysses. Neuere deutsche Aufsätze (cit. fn. 43), pp. 80-I04, here: p. 82.

${ }^{49}$ ) Qtd. ibid., p. 85 .

${ }^{50}$ ) Kenner, Ulysses (cit. fn. 3), p. 65.

${ }^{51}$ ) Goldman, The Joyce Paradox (cit. fn. 3), p. 99. 
gerung zunächst gerade die objektiv traditionelle Seite der musikalischen Sprache negierte. [...] Aus der Dialektik tritt am Ende das Naturmaterial bedrohlich rein hervor. ${ }^{52}$ )

Adorno problematises a regression towards natural material because, in his opinion, dodecaphony - analogous to late-capitalist society - rationalizes musical composition and restricts the freedom of the individual. Joyce scholars repeatedly maintain that a primary goal of his literary project was "to transcend the barriers of expressiveness set by the systems of existing languages", while at the same time emphasising "the elements of chance and fluidity that Joyce was increasingly willing to admit into the mechanics of literary composition." ${ }^{53}$ ) Parts of ,Ulysses (for example, the penultimate chapter) border on deterministic writing. ${ }^{54}$ ) Adorno again attributes the alienating power of chance and determinism to the twelve-tone technique:

Total determination borders on chance insofar as totally constructed music appears to the individual as strange and incommensurable as does contingency.

(Die totale Determination berührt insofern sich mit dem Zufall, als die durchkonstruierte Musik dem Subjekt als ein so Fremdes und Inkommensurables gegenübertritt wie Zufallsereignisse. $)^{55}$ )

The principle of fragmentation and a concentration on the materiality of language - evident in Chapter Ten of ,Ulysses - is a key principle of Chapter Fourteen ("Oxen of the Sun"). There, the individual paragraphs draw on prose styles taken from the history of English literature and, at the end of the chapter, contemporary dialects and slang. They form "a frightful jumble of Pidgin English, nigger English, Cockney, Irish, Bowery slang and broken doggerel" $\left.{ }^{\prime 6}\right)$ used by Joyce for parodic purposes. The chapter starts with phrases from chronicles - alliterating Anglo-Saxon ("Before born the babe had bliss. Within the womb he won worship") ${ }^{57}$ ) - and medieval morality plays and epics, before crossing to the $16^{\text {th }}$ and $17^{\text {th }}$ centuries, then parodying Defoe, Swift, Sterne, and Goldsmith, before finally traversing the $19^{\text {th }}$ century up to Ruskin and Pater. Semantics are almost lost along the way; the sequence of historical literary styles performs the development of the human embryo in

${ }^{52}$ ) Theodor W. Adorno, Über das gegenwärtige Verhältnis von Philosophie und Musik, in: Musikalische Schriften V (Gesammelte Schriften I8), Frankfurt/M 1984, pp. I49-176, here: pp. I6I-I62; engl. translation N. B.

53) Laurent Milesi, Introduction: language(s) with a difference, in: James Joyce and the Difference of Language, ed. by L. M. Cambridge 2003, pp. I-27, here: p. I.

${ }^{54}$ ) Clive Hart, Structure and Motif in Finnegans Wake, London i962, p. 65.

${ }^{55}$ ) Theordor W. Adorno, Zum Stand des Komponierens in Deutschland, in: Musikalische Schriften V (cit. fn. 52), pp. I34-I39, here: p. I38, engl. translation N. B.

${ }^{56}$ ) James Joyce, Ulysses, ed. with an Introduction and Notes by Jeri Johnson, Oxford 2008, p. 906.

57) Ibid., p. 367. 
a linguistic form. The 'contents' of the chapter - the birth of a child - could be told in one sentence. In this chapter the text is, therefore, actually selfreferential and generated exclusively out of language.

For the final time, we will turn to Adorno as a guide in our comparison. In his discussion of the relationship between repetition and variety in Schönberg's dodecaphony, he observes that the variation of a given sequence of tones becomes the force creating musical dynamics; composing with twelve tones, therefore, renders variation the ultimate principle ("das Variationsprinzip zur Totalität, zum Absoluten"). ${ }^{58}$ ) For Joyce linguistic variation is also a primary creative principle. Fritz Senn calls permanent stylistic re-formation ("fortwährende stilistische Re-Formation") the central feature of ,Ulysses.$^{59}$ ) Sometimes, in the case of Joyce's catalogues, the series of variations aim at encyclopaedic completeness. His catalogues count amongst his key experimental writing techniques; they perform the "exploitation, to the point of explosion, of a given 'programme". ${ }^{60}$ ) This linguistic transformation is evident in the passage featuring "Sindbad the Sailor", which introduces Ulysses' travel companions.

Sindbad the Sailor and Tindbad the Tailor and Jinbad the Jailer and Whinbad the Whaler and Ninbad the Nailer and Finbad the Failer and Binbad the Bailer and Pinbad the Pailer and Minbad the Mailer and Hinbad the Hailer and Rinbad the Railer and Dinbad the Kailer and Vinbad the Quailer and Linbad the Yailer and Xinbad the Phthailer. ${ }^{61}$ )

Furthermore, as a supplement to this sequence, Joyce mentions "Darkinbad the Brightdayler". The initial sounds - B (C) D F (G) H J K L M N P Q R S T V W X Y Z (Phth) - may be compared to one of Schönberg's primary series (Grundreihen). The initial sounds cover almost all available consonants, only $\mathrm{C}$, which phonetically coincides with $[\mathrm{k}]$ or $[\mathrm{s}]$; $\mathrm{G}$, that is phonetically partly identical with J (or [dž], to be exact); and Z, which is transmogrified to "Phth" (although this form is probably meant to indicate a speech defect) are lacking. Joyce regularly employs such small 'errors' or deviations from the system - a trait he has in common with Schönberg who also frequently deviates from the strict rules of serial composition..$^{62}$ )

The paragraph declining Leopold Bloom's name also relies on variation as the principle of text generation ("Bloom. Of Bloom. For Bloom. Bloom; Bloowho, Bloowhose, Bloohimwhom"), expanding it (“Booloohoom, Bloohoom”),

${ }^{58}$ ) Adorno, Philosophie der neuen Musik (cit. fn. 22), p. 99.

59) Fritz Senn, Odysseische Metamorphosen, in: James Joyces ,Ulysses«. Neuere deutsche Aufsätze, es. by Therese Fischer-Seidel, Frankfurt/M I977, pp. 26-57, here: p. 27.

$\left.{ }^{60}\right)$ Milesi, Introduction (cit fn. 53), p. 7.

${ }^{61)}$ Joyce, Ulysses (cit. fn. 56), p. 689.

${ }^{62}$ For examples of such 'errors' or deviations see Ganter, Ordnungsprinzip oder Konstruktion (cit. fn. 5), pp. 23 (from piano piece, op. II, no. I), and I45f. (from piano piece, op. 23, no. 3). 
or interpreting it as a relative pronoun and associating it with homophones (blue, blew). "Elpodbomool" and "Old Ollebo, M. P." are anagrams that are reminiscent of inversions in music, while "Virag", "O’Bloom", "Don Poldo de la Flora", "Senhor Enrique Flor", "Henry Fleury", and "Professor Luitpold Blumenduft" are translations of his name into Hungarian, Irish, Spanish, Portuguese, French, and German reminiscent of keychanges. A typo changes the hero's name to "L. Boom", verbal forms such as "blooming" and "blometh", the exploitation of the pseudo-etymological relation with 'blood' in "bloody" and the association with trousers ("bloomers") and place names ("Bloom Village", "Bloomville"), more of transmogrification with "Bloomusalem", and the invention of a group of supporters ("Bloomites") follow. ${ }^{63}$ )

\section{Writing/Composing Under Constraints}

In the case of Schönberg and Joyce, composing and writing according to external structural parameters or constraints comprises, in particular, the use of the twelve chromatic tones in a certain order of succession and the so-called Gilbert and Linati schemata, respectively. External structural parameters, and in particular numerical or topographical patterns, are common in experimental writing; their main purpose is to disturb or even destroy the principles and illusion of a mimetic narrative. ${ }^{64}$ ) The use of such techniques amply demonstrates how flexible the 'material' - literary language and the tonal system - really is, and how easily this material may be liberated of its conventional semantics. Adorno hyperbolically interprets serial dodecaphony as determining every single note ("Jeder Ton der gesamten Komposition ist durch diese 'Reihe' determiniert, es gibt keine 'freie' Note mehr") ${ }^{65}$ ), and maintains that musical sequences are dominated by contingency, chance, restless permutation, and mechanical patterns. ${ }^{66}$ ) There is, however, ample consensus that the twelve-tone technique realizes the rational organization of the entire musical material ("Idee einer rationalen Durchorganisation des gesamten musikalischen Materials") ${ }^{67}$ ) and that a mathematical coherence ("Stimmigkeit als ein mathematisches Aufgehen") replaces the inspiration and idea of conventional composition ("was der traditionellen Kunst 'Idee' hieß”). ${ }^{68}$ )

63) These examples are qtd. in Senn, Odysseische Metamorphosen (cit. fn. 59), pp. 35-37.

${ }^{64)}$ See Ulrich Ernst, Typen des experimentellen Romans in der europäischen und amerikanischen Gegenwartsliteratur, in: Arcadia 27 (1992), pp. 225-320.

${ }^{65}$ Adorno, Philosophie der neuen Musik (cit. fn. 22), p. 63.

${ }^{66)}$ Cf. ibid., p. 74.

$\left.{ }^{67}\right)$ Ibid., p. 56.

${ }^{68)}$ Ibid., p. 67. 
Schönberg himself was aware of the constraints inherent in the use of sequences of twelve tones: he was trying to overcome the obstacles to creation, following the free flow of composing ("dem freien Schaffen flüssiger Schreibweise"). ${ }^{69}$ ) As we have already shown, dodecaphonic compositions are constructed according to constraints to a certain extent. This statement applies also to 'Ulysses«. Joyce tries to explore systematically certain spaces of possibilities and variants. The 'catalogues' introduced above, which work according to certain specifications, represent external constraints on a micro level. Such constraints, however, also exist on the macro level of ,Ulysses‘, such as the series of newspaper articles in Chapter Seven, the musical forms imitated in Chapter Eleven, and the sequence of prose styles in Chapter Fourteen. In two schemata named after their recipients - the Gilbert and Linati schemata - Joyce assigns seven categories (or constraints) to each of the eighteen chapters, out of which at least six must be realized. Each chapter, therefore, contains certain figures, settings, and actions from Homer's $>$ Odyssey time of day, an organ of the human body, an art or science, a colour, a symbol, and a (rhetorical) technique ${ }^{70}$ ) (s. fig. 6).

This schema dates from a late phase in the genesis of the novel; it is partly the result of an analysis of chapters already finished in draft, while also providing a number of 'constraints' for the final revision of the text. Some critics regard the schema as a fake, destined to set readers on wrong tracks, ${ }^{71}$ ) but after all ,Ulysses does raise an encyclopaedic claim. In the words of Stanzel, the novel experiments with the totality of ways to describe the world ("ein Experiment mit der Totalität der Darstellungsmöglichkeiten unserer Welt im Roman”). ${ }^{72}$ )

At the end of his >Harmonielehre of I9II - which is placed at the end of the book to make it appear as a thought experiment - Schönberg envisions the systematic exploration of the possibilities of working with the twelve chromatic tones. He suggests using all possible gamuts, including rare and exotic scales ("in der europäischen Kunstmusik nicht oder nur selten verwendete[] exotische[] Tonarten"). ${ }^{73}$ ) The twelve-tone technique is easily recognizable as the realization of this idea. As we have already mentioned in our short analysis of the piano piece op. 25, the basis of each composition using twelve tones was a row or a number of sequences. Schönberg drew several charts which reveal his efforts to systematically explore tonal space. The charts for his String quartet No. 3, op. 30 (1927) include the twelve versions of the primary series, starting

${ }^{69}$ ) Qtd. in Ganter, Ordnungsprinzip oder Konstruktion (cit. fn. 5), p. 82.

${ }^{70}$ ) See figure I: The Gilbert schema (from: Joyce, Ulysses, cit. fn. 56), pp. $736 f$.

$\left.{ }^{71}\right)$ See Herring, Zur Textgenese des ,Ulysses (cit. fn. 48), pp. 87 f.

$\left.{ }^{72}\right)$ Stanzel, Die Personalisierung des Erzählaktes im ,Ulysses‘, p. 293.

73 ) SснÖnberg, Harmonielehre (cit. fn. 32), p. 464. 


\author{
Appendix A
}

The Gilbert and Linati Schemata

Table of Correspondences

THE GILBERT SCHEMA

\begin{tabular}{|c|c|c|c|c|c|c|c|c|}
\hline Title & Scene & Hour & Organ & Art & Colour & Symbol & Technic & Correspondences \\
\hline \multicolumn{9}{|c|}{ I. TELEMACHIA } \\
\hline I. Telemachus & The Tower & 8 a.m. & . & Theology & white, gold & Heir & $\begin{array}{l}\text { Narrative } \\
\text { (young) }\end{array}$ & $\begin{array}{l}\text { Stephen: Telemachus, Hamlet; Buck } \\
\text { Mulligan: Antinous; Milkwoman: } \\
\text { Mentor. }\end{array}$ \\
\hline 2. Nestor & The School & ro a.m. & & History & brown & Horse & $\begin{array}{r}\text { Catechism } \\
\text { (personal) }\end{array}$ & $\begin{array}{l}\text { Deasy: Nestor; Sargent: Pisistratus; } \\
\text { Helen: Mrs O'Shea. }\end{array}$ \\
\hline 3. Proteus & The Strand & II a.m. & & Philology & green & Tide & $\begin{array}{l}\text { Monologue } \\
\text { (male) }\end{array}$ & $\begin{array}{l}\text { Proteus: Primal Matter; Menelaus: } \\
\text { Kevin Egan; Megapenthes: The } \\
\text { Cocklepicker. }\end{array}$ \\
\hline \multicolumn{9}{|c|}{ II. ODYSSEY } \\
\hline 4. Calypso & The House & 8 a.m. & Kidney & Economics & orange & Nymph & $\begin{array}{r}\text { Narrative } \\
\text { (mature) }\end{array}$ & $\begin{array}{l}\text { Calypso: The Nymph; The Recall: } \\
\text { Dlugascz; Ithaca: Zion. }\end{array}$ \\
\hline s. Lotus Eaters & The Bath & Io a.m. & Genitals & $\begin{array}{l}\text { Botany, } \\
\text { Chemistry }\end{array}$ & & Eucharist & Narcissism & $\begin{array}{l}\text { Lotus Eaters: Cabhorses, Com- } \\
\text { municants, Soldiers, Eunuchs, Bather, } \\
\text { Watchers of Cricket. }\end{array}$ \\
\hline 6. Hades & The Graveyard & II a.m. & Heart & Religion & white, black & Caretaker & Incubism. & $\begin{array}{l}\text { The } 4 \text { Rivers: Dodder, Grand and } \\
\text { Royal Canals, Liffey; Sisyphus: } \\
\text { Cunningham; Cerberus: Father } \\
\text { Coffey; Hades: Caretaker; Hercules: } \\
\text { Daniel O'Connell; Elpenor: Dignam; } \\
\text { Agamemnon: Parnell; Ajax: Menton. }\end{array}$ \\
\hline 7. Aeolus & The Newspaper & 12 noon & Lungs & Rhetoric & red & Editor & Enthymemic & $\begin{array}{l}\text { Aeolus: Crawford; Incest: Journalism; } \\
\text { Floating Island: Press. }\end{array}$ \\
\hline 8. Lestrygonians & The Lunch & I p.m. & Esophagus & \multicolumn{2}{|l|}{ Architecture } & Constables & Peristaltic & $\begin{array}{l}\text { Antiphates: Hunger; The Decoy: } \\
\text { Food; Lestrygonians: Teeth. }\end{array}$ \\
\hline $\begin{array}{l}\text { 9. Scylla and } \\
\text { Charybdis }\end{array}$ & The Library & 2 p.m. & Brain & \multicolumn{2}{|l|}{ Literature } & $\begin{array}{l}\text { Stratford, } \\
\text { London }\end{array}$ & Dialectic & $\begin{array}{l}\text { Rock: Aristotle, Dogma, Stratford; } \\
\text { Whirlpool: Plato, Mysticism, } \\
\text { London; Ulysses: Socrates, Jesus, } \\
\text { Shakespeare. }\end{array}$ \\
\hline $\begin{array}{l}\text { 10. Wandering } \\
\text { Rocks }\end{array}$ & The Streets & 3 p.m. & Blood & Mechanics & & Citizens & Labyrinth. & $\begin{array}{l}\text { Bosphorus: Liffey; European bank: } \\
\text { Viceroy; Asiatic bank: Conmee; } \\
\text { Symplegades: Groups of citizens. }\end{array}$ \\
\hline II. Sirens & $\begin{array}{l}\text { The Concert } \\
\text { Room }\end{array}$ & 4 p.m. & Ear & Music & & Barmaids & $\begin{array}{l}\text { Fuga per } \\
\text { canonem }\end{array}$ & $\begin{array}{l}\text { Sirens: Barmaids; } \\
\text { Isle: Bar. }\end{array}$ \\
\hline 12. Cyclops & The Tavern & s p.m. & Muscle & Politics & & Fenian & Gigantism & $\begin{array}{l}\text { Noman: I; Stake: cigar; Challenge: } \\
\text { apotheosis. }\end{array}$ \\
\hline 13. Nausicaa & The Rocks & 8 p.m. & Eye, Nose & Painting & grey, blue & Virgin & $\begin{array}{l}\text { Tumescence, } \\
\text { detumescence }\end{array}$ & $\begin{array}{l}\text { Nausicaa: Nymph; Phaecia: Star of } \\
\text { the Sea. }\end{array}$ \\
\hline $\begin{array}{l}\text { 14. Oxen of } \\
\text { the Sun }\end{array}$ & The Hospital & Io p.m. & Womb & Medicine & white & Mothers & $\begin{array}{l}\text { Embryonic } \\
\text { development }\end{array}$ & $\begin{array}{l}\text { Trinacria: Hospital; Lampetie, } \\
\text { Phaethusa: Nurses; Helios: Horne; } \\
\text { Oxen: Fertility; Crime: Fraud. }\end{array}$ \\
\hline Is. Circe & The Brothel & $\begin{array}{l}12 \text { mid- } \\
\text { night }\end{array}$ & $\begin{array}{l}\text { Locomotor } \\
\text { apparatus }\end{array}$ & Magic & & Whore & Hallucination & Circe: Bella. \\
\hline \multicolumn{9}{|c|}{ III. NOSTOS } \\
\hline 16. Eumaeus & The Shelter & r a.m. & Nerves & Navigation & & Sailors & $\begin{array}{l}\text { Narrative } \\
\text { (old) }\end{array}$ & $\begin{array}{l}\text { Eumaeus: Skin-the-Goat; Ulysses } \\
\text { Pseudangelos: Sailor; Melanthius: } \\
\text { Corley. }\end{array}$ \\
\hline 17. Ithaca & The House & 2 a.m. & Skeleton & Science & & Comets & $\begin{array}{l}\text { Catechism } \\
\text { (impersonal) }\end{array}$ & $\begin{array}{l}\text { Eurymachus: Boylan; } \\
\text { Suitors: scruples; Bow: reason. }\end{array}$ \\
\hline 18. Penelope & The Bed & - & Flesh & - & & Earth & $\begin{array}{l}\text { Monologue } \\
\text { (female) }\end{array}$ & $\begin{array}{l}\text { Penelope: Earth; } \\
\text { Web: movement. }\end{array}$ \\
\hline
\end{tabular}


from all chromatic tones, and the same series 'inverted'; see figure 2. Further basic series are produced by reading the twenty-four series backwards ('Krebs' and 'Krebs-Umkehrung') ${ }^{74}$ ) (fig. 7 and 8):
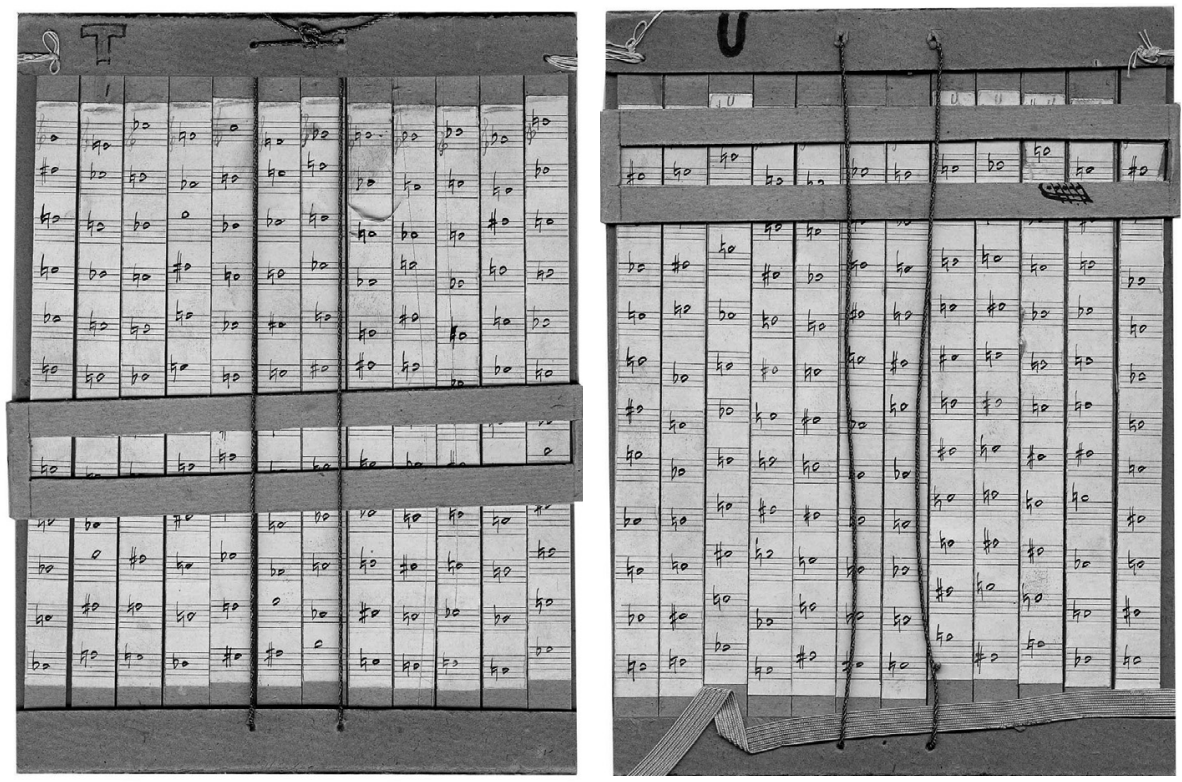

Surveying a field of possibilities played not only an important role in the arts but also in psycho-physical research. Hermann Ebbinghaus, for example, tried to empirically test the capacity of human memory to memorise randomly generated syllables. The words of three syllables, each entirely meaningless according to 'natural' language usage, were constructed out of a pool of eleven vocal sounds, nineteen initial sounds, and eleven final sound consonants, with the total number of possible combinations, therefore, equalling 2299 (II $\times$ I9 $\times$ II). Friedrich Kittler compares this experiment with avant-garde sound and nonsense poetry of the early twentieth century and with dodecaphony. Ebbinghaus formed groups of 7 to 26 elements - similar to the twelve-tone sequences - with elements that had already been used eliminated from the pool until all other elements had been used up. Finally, like Schönberg and Joyce, Ebbinghaus broke his own rules by sometimes deviating from these strict constraints. Crucially, a comparison of the two 'experiments' reveals that the rather complex principles

$\left.{ }^{74}\right)$ See Figure: Row charts to String quartet No. 3, op. 30 (1927), primary row (left) and inversion (Umkehrung, right) starting from the twelve chromatic tones (reprinted courtesy of the Arnold Schönberg Center, Vienna). 
of arranging the material were intended to remove language and music as far away as possible from their 'natural' use. According to Kittler, nonsensical syllables and equal chromatic tones constitute media in the modern sense and random selections create a pool of material that is selected in order to form individual aggregates ("Unsinnssilben oder gleichberechtigte chromatische Töne konstituieren Medien im modernen Sinn: vom Zufallsgenerator ausgeworfene Materialmengen, deren Selektion dann einzelne Komplexe bildet”). ${ }^{75}$ )

\section{Semantic Derestriction: 'Finnegans Waker, Read by the Interpretive Community}

A final analysis of 'Finnegans Waker will focus on one particular aspect that offers a productive analogy with Schönberg's mode of composition, namely the way in which the words in 'Finnegans Waker are removed from their languages of origin and manipulated, in order to evoke a sense of the plurality of languages. Similarly, language in Joyce's last work is semantically deristricted; connections are drawn etymologically between languages, through the use of similar sounds. Key techniques include:

- the exchange of words sounding identical or similar (homonyms): 'eye' - 'I', 'tail' - 'tale', 'bedoueen' - 'between', 'Finnagain' - 'Finnegan';

- the use of portmanteau words: 'Babbel': 'Babel' - 'to babble'; 'isthmass': 'isthmus' - 'mass' - 'Christmas'; 'phoenish': 'phoenix' - 'finish';

- the splitting-up of a word into two or more words: 'Mississippi' and 'Missouri': 'missus', 'seepy' and 'sewery';

- the replacement of single letters: Lord - load - loud; february -febrewery;

- the transmogrification of quotations and locutions: 'Maria, full of grace' 'Maria, full of grease'; 'Ring out the old, ring in the new' - 'Wring out the clothes! Wring in the dew!'

- sound associations across languages, aka surface translation: 'Send-us-pray' 'Saint Esprit'; Sophy Key-Po - Sauve qui peut. ${ }^{76}$ )

${ }^{75)}$ Friedrich A. Kittler, Aufschreibesysteme i80o i900. Dritte, vollständig überarbeitete Neuauflage, München 1995, pp. 264f. The parallels with other spaces of possibilities may be augmented. According to an anecdote Schönberg got the inspiration for the twelve-tone technique in a Viennese café where the menu offered different sorts of coffee by a chart of twelve numbered shades of brown referring to the different mixtures of coffee and milk; cf. Gerhard Persché, Behutsame Annäherung. Frank Scheffers musikalische Dokumentarfilme beim Festival „Wien Modern“, in: Süddeutsche Zeitung, Stadt-Ausgabe, 29 November 2007, p. I3.

$\left.{ }^{76}\right)$ These categories and the corresponding examples are taken from Klaus Reichert, Vielfacher Schriftsinn. Zu Finnegans Wake, Frankfurt/M 1989, p. 71. 
These techniques are reminiscent of the disturbances of speech and the products of language disintegration ("Sprachzersetzungsprodukte") ${ }^{77}$ ) that generated scientific interest at the turn of the $20^{\text {th }}$ century. This scientific interest shifted from the conventional collection of meanings to the signifier and the associations it produces. In his , Grundzüge der Psychologie,, Ebbinghaus records his experiments testing the emergence of linguistic associations. When trying to memorise nonsensical syllables the test subjects tended, in spite of explicit recommendations not to do so, to develop all kinds of secondary associations:

Unsystematically the most heterogeneous things come to their mind: consonance of syllables, relations between letters, similar nonsense words or names of persons, animals, and so on, meanings in another language, etc. [...]. Thus, pek becomes Peking, kin becomes Kind, sep reminds them of Joseph, neis of English nice, schuk of French choucroute. [...] The syllables faak neit are associated with Fahrenheit by one proband, another test-person in the case of jas dum - via the French jaser - thinks of dummes Geschwätz; the sequence of the syllables dosch päm feur löt was interpreted as: das Brot Feuer löscht.

(Es fällt ihnen dabei etwas ein, und zwar bunt durcheinander das Allerverschiedenste: ein Gleichklang von Silben, Beziehungen von Buchstaben zueinander, ähnlich lautende sinnlose Worte oder Namen von Personen, Tieren u. a., Bedeutungen in einer fremden Sprache usw. [...] So wird z. B. pek zu Peking ergänzt, kin zu Kind; sep erinnert an Josef, neis an das englische nice, schuk an das französische choucroute. [...] Die Silben faak neit weckten z. B. bei einer Versuchsperson die Vorstellung Fahrenheit, jas dum bei einer anderen (durch Vermittelung des französischen jaser) die Vorstellung dummes Geschwätz; die Silbenfolge dosch päm feur löt wurde einmal zu dem Sätzchen verbunden: das Brot Feuer löscht. ${ }^{78}$ )

'Language disintegration', avant la lettre, is reminiscent of deconstruction. Famously, Finnegans Waker has often been interpreted as laying the ground work for post-structuralist theory and writing, with Jacques Derrida, Hélène Cixous, Julia Kristeva, Jacques Lacan, Fredric Jameson, and many more praising Joyce in this respect. ${ }^{79}$ ) Brian McHale states of ,Finnegans Waker that "there is no stable world behind this consciousness, but only a flux of discourse in which fragments of different, incompatible realities flicker into existence and out of existence again, overwhelmed by the competing reality of language. Postmodernist fiction, in short." ${ }^{80}$ )

Language is even more central to 'Finnegans Waker than to 'Ulyssesı. In the former, words, and in particular their sounds, are the main 'contents',

${ }^{77}$ ) Kittler, Aufschreibesysteme (cit. fn. 75), p. 274.

${ }^{78}$ ) Hermann Ebbinghaus, Grundzüge der Psychologie, erster Band, vierte Auflage bearbeitet von Karl BüHLER, Leipzig 19I9, p. 717, engl. translation N. B.

${ }^{79}$ ) Cf. Derek Attridge and Daniel Ferrer (eds.), Post-structuralist Joyce. Essays from the French, Cambridge 1984 .

80) Brian McHale, Postmodernist Fiction, London 1987, p. 234. 
with languages sometimes performing "presemantic sounds". ${ }^{81}$ ) Language is, throughout the text, close to music, something which Joyce has used to explain the peculiarities of style: "He defended its technique or form in terms of music, insisting not on the union of the arts - although that seems to be implied - but on the importance of sound and rhythm, and the indivisibility of meaning from form [...]." ${ }^{82}$ )

In 'Finnegans Waker text is only present as text. "Here we are not inclined to ignore the medium whereby the content is transmitted; this is language at its least transparent [...]. Indeed it is difficult to talk of a 'content' that is somehow behind these words, pre-existing and predetermining them [...]." ${ }^{83}$ ) Liberating words from their conventional meaning and usage may once more be paralleled with Schönberg's use of the twelve-tone technique. Whereas tones have a fixed 'meaning' in functional harmonics that may be rightly compared with conventional narrative, in dodecaphony they are free to enter into relation with all other tones of the chromatic scale. The freedom of linguistic association, therefore, directly compares to the freedom of tonal association. Schönberg's own description of the new mode of composition - "Method of Composing with Twelve Tones Which are Related Only with One Another" ${ }^{84}$ ) - speaks to the idea of free tonal association making music truly autonomous.

The multiplicity of meaning apparent in the universal language of sFinnegans Waker is demonstrated by the many readings of the novel's first word "riverrun". The interpretations below are taken from "Finnegans Wiki", a website dedicated to collective commentary of the text. ${ }^{85}$ )

The entry 'riverrun' mentions a number of intertextual references:

Genesis 2:10: And a river went out of Eden to water the garden; and from thence it was parted, and became into four heads. - Revelation 22:I: "And he shewed me a pure river of water of life, clear as crystal, proceeding out of the throne of God and of the Lamb." Samuel Taylor Coleridge, Kubla Khan: Or, A Vision in a Dream. A Fragment, lines I-4: "In Xanadu did Kubla Khan / A stately pleasure-dome decree: / Where Alph, the sacred river, ran / Through caverns measureless to man / Down to a sunless sea." $\rightarrow$ with a possible hint that this word is the Alpha of FW and symbolizes ALP. For Kubla Khan see FW 32. The allusion to Coleridge's Kubla Khan leaves enough room for speculations: the poem came to Coleridge during a drug-induced dream $\rightarrow$ reverie; from author's note published with the poem: "On awakening he appeared to himself to have a distinct recollection of the whole,

${ }^{81}$ Milesi, Introduction (cit. fn. 53), p. 5.

${ }^{82}$ Richard Ellmann, James Joyce. New and Revised Edition, New York, Oxford, Toronto I982, p. 703.

83) Derek Attridge, Reading Joyce, in: The Cambridge Companion to James Joyce, ed. by D. A. Cambridge I990, pp. I-30, here: p. I0.

$\left.{ }^{84}\right)$ See E. Randol Schoenberg, The Most Famous Thing He Never Said (cit. fn. 7), p. 29.

${ }^{85}$ ) See <http://www.finnegansweb.com/wiki/index.php/riverrun> [I2.08.2019]. 
and taking his pen, ink, and paper, instantly and eagerly wrote down the lines that are here preserved" $\rightarrow$ Erinnerung; "At this moment he was unfortunately called out by a person on business from Porlock, and detained by him above an hour, and on his return to his room, found, to his no small surprise and mortification, that though he still retained some vague and dim recollection of the general purport of the vision, yet, with the exception of some eight or ten scattered lines and images, all the rest had passed away like the images on the surface of a stream into which a stone has been cast, but, alas! without the after restoration of the latter!" $\rightarrow$ the smooth flow of words is interrupted by thunder, producing charosmatic world of FW. - Alfred Tennyson, Dying Swan, lines 5-6: "With an inner voice the river ran, / Adown it floated a dying swan, / And loudly did lament."

Associations with the names of rivers are further noted:

River Jordan: a river in the Holy Land $\rightarrow$ Giordano Bruno, whose name means literally "Brown Jordan" $\rightarrow$ the River Liffey (FW I94.22 turfbrown mummy) $\rightarrow$ the Liffey as Dublin's sewer $\rightarrow$ jordan = a chamber-pot. Giordano wrote mnemonic works (see Erinnerung above). - elvelop: (Norwegian) the course of the river, translates directly as riverrun (river - elv; run - lop (noun or imperative) - rivo (Latin) from (v) rivus (“brook; channel”): "I lead" or "I draw off".

The following part of the entry is dedicated to the phonetic similarity of 'riverrun' with German 'Erinnerung' and to the connection of this concept to the conception of 'Finnegans Wake in general:

Erinnerung: (German) remembrance; memory (i. e. a thing remembered) - Vico, The New Science 819: "... memory is the same thing as imagination ... the theological poets called Memory the mother of the Muses"; - Sigmund Freud, The Interpretation of Dreams (Chapter 5): Freud identifies memories as a principal source of the manifest content of dreams.

At this point another field of reference comes into play.

reverie: $(n)$ a state of dreaming while awake, a daydream; a fantastic, visionary, or impractical idea; (music) an instrumental composition of a vague and dreamy character

Two further names of rivers, one of them with musical associations, follow:

river Rhone $\rightarrow$ river runs from Swiss Alps to the Mediterranean Sea - river Rhine $\rightarrow$ cf. the connections between FW and Wagner's operatic tetralogy Der Ring des Nibelungen, which starts with the theft of the gold in Das Rheingold, and ends with the gold being Given! (FW 628.15) back to the Rhinemaidens at the conclusion of Gotterdammerung. - riverain: (adj) pertaining to a river or a riverbank; situated or dwelling on or near a river; $(n)$ a district situated beside a river.

Another important association is the word 'reverend' and individual parts of this word:

reverend: (informal) a member of the clergy - Reverend: (adj) 1. (initial capital letter) used as a title of respect applied or prefixed to the name of a member of the clergy or a religious order, cf. ALP's letter (FW 6I5 ff): “Dear. And we go on to Dirtdump. Reverend.”; 2. worthy 
to be revered; entitled to reverence; 3. pertaining to or characteristic of the clergy - Reverend Jonathan Swift's Gulliver's Travels was also a Menippean satire of decadence - err: to make a mistake; to sin; to wander from the right way; to go astray - Cf. A Portrait of the Artist as a Young Man: "To live, to err, to fall, to triumph, to recreate life out of life!" It's hard to find any better description for Joyce's art in general and FW in particular. - run (Old English) mystery, secret; advice, counsel; writing; a rune - ri- (Italian) Prefix used with verbal roots to mean repetition; re-, again - ricorso (Italian) $=$ return $\rightarrow$ Vico's ricorso storico (historical return).

Finally, Italian, French, and German verbs and nouns, Irish echoes and some rather distant associations (translations, Old Norse, the constellation of Eridanos representing the river into which Phaeton fell) are suggested. These examples show that the possible associations drawn from `Finnegans Wake are virtually unlimited.

riverranno: (Italian) they will return; they will come back - riveran: (Italian Dialect) they will arrive - riverain: (French) inhabitant - reverons: (French) let us dream - reveries: (French) day-dreams; reveries; ravings; delusions - reverrons: (French) let us see again reverence: (French) curtsey - rief heran: (German) he or she called or summoned somebody - Ragnarok: (Old Norse) fate of the gods; twilight of the gods; end of the world - liv amhran: (L/R split) Liv (Titus Livius, Vico’s "first loved” historian; Anna Livia Plurabelle; Lucia Joyce ) + Irish "sing". - Rivalin: Tristram's father $\rightarrow$ L/R split - water faucet: is there a wash hand basin with a tap in the corner of HCE's bedroom? $\rightarrow$ the 1 st of 7 elements in a circuit of HCE's bedroom - watercourse $\rightarrow$ the Latinism-Saxonism of "river-run" becomes the Saxonism-Latinism of "water-course" - riverrun $\rightarrow$ Eridanos; Nonnus, Dionysiaca 23: "I will drag down from heaven the fiery Eridanos whose course is among the stars, and bring him back to a new home in the Celtic land: he shall be water again, and the sky shall be bare of the river of fire." - ribhéar a rúin, Irish for 'my darling river' - Rún (Irish) a riddle, a mistery.

\section{Conclusion}

As described in the introduction, Schönberg's und Joyce's innovations occurred almost in perfect synchrony in I92 I, with preparatory plans going back to 1908 . Both artists took a critical look at the basics of their material, namely language, narrative, and tonality respectively. They foregrounded the surface of the text, the signifier, and the tonal system. The literary and musical languages lose their conventional meanings and functional attributes. Joyce dissolves clear-cut narrative positions such as the personal and omniscient narrators. Certain passages in >Ulysses can no longer be easily attributed to individual characters and therefore turn - borrowing a term from post-modern dramatic theory - into textual areas ('Textflächen'). Schönberg abandons tonality and the theory of functional harmony. Instead of 'telling' a musical 'story', which begins at a cer- 
tain key and makes its way through the piece by means of conventional chord progressions up until a happy ending which returns once again to the opening key, he strings together a sequence of small musical fragments (motifs) that are determined by the necessity of containing all of the twelve chromatic tones.

Thus, both Schönberg's compositions and Joyce's texts are structured according to external constraints. Schönberg uses tone sequences that are defined in advance and largely determine the progression of the composition, in particular pitch and chords and, to a certain extent, also voice leading. In „Ulysses the Gilbert and Linati schemata determine a set of conditions that must be fulfilled in the individual chapters. On the textual micro level 'catalogues' parse a linguistic phenomenon in every detail and in all possible variations, something which is also true for a dodecaphonic sequence in a composition that tries out all possible applications and variants of a musical motif or constellation. In both cases a space of possibilities is explored. On the other hand, the creative subject - the artist's personality - loses some of its power as creator of the work of art; in general, modernism is sceptical with regard to the conveying of certain messages or feelings. It is little surprise that the majority of contemporary criticism was not in favour of such a depersonalization of artistic procedures. Even well-informed critics like Adorno regretted that determination in art - mirroring the alienation in capitalist society - replaced free expression of the individual. In 'Finnegans Waker the deconstruction of language is even more radical than in UUlysses. The mixture of various languages in a highly artificial idiom renders the search for meaning a journey without any definable end - the possibilities of interpretation and association are virtually unlimited. In analogy to this development, the tones in dodecaphony also allow for free association - 'absolute' music that is free from any form of narrative mimesis implies equal relations with all the other eleven tones of the chromatic scale. The emancipation of dissonance opens up and expands the possibilities of musical association. 